\title{
Restoration as a Social Cohesion Instrument: Vila Itororó in Central São Paulo
}

\author{
Benjamim Saviani \\ Instituto Pedra, São Paulo, Brazil \\ benjamim@institutopedra.org.br
}

\begin{abstract}
Recently, the restoration work of Vila Itororó-an architectural complex in central São Paulo, built around the 1920s, has been carried out, enabling applied field research for restoration as well as for historical perspective of the social and cultural development that took place at Vila Itororó. Alongside the restoration work, a cultural centre has been installed on the site, embracing the opportunities of creating a new agenda for Vila Itororó with the community while the restoration takes place. Through this, Vila Itororó has been able to bring the discussion and practise of restoration closer to the civil society, reaching a public beyond the academic circles. The rich environment produced by these efforts has allowed for an outlet of publications and discussions regarding issues that range from architectural prospection to the role that heritage can play with our society in the city of the $21^{\text {st }}$ century. This paper intends to present some of these discussions, their origins, insights and other findings that this experience has fostered.
\end{abstract}

KEYWORDS Brazil, São Paulo, Vila Itororó, architectural prospection, restoration work

Received September 13, 2017; accepted February 2, 2018.

\section{Introduction: Territory}

São Paulo is a city approximately 500 years old. By the end of the $19^{\text {th }}$ century it was a small town, and grew dramatically, creating intense transformations within the urban space. The region is composed of a series of water courses and inclined landscape. In a way, these factors conditioned the city's growth up until this rapid expansion.

When built, Vila Itororó was located in an expanding area. The site is set among within an elite neighbourhood, yet with a surprisingly vertical landscape, near watersheds. These factors made the site less sanitary, which drove the prices down in comparison to the surrounding sites.

It was on these cheaper lands that Francisco de Castro, a textile and coffee commercial representative of Portuguese ascendance, arrived in the beginning of the $20^{\text {th }}$ century. His plan was to build a home surrounded by other houses he could rent out to others. He had a role in many other affairs and business ventures with the local community.

\section{History: Morphology and Occupation}

The area of interest includes 11 buildings in addition to an industrial shed connected to the site, all of which date back to the 1930s. All buildings except the shed contained at least one housing unit, and a few of those had mixed uses, which varied over the years. To identify each building the project team has numbered them from 1 to 11, again with the exception of the shed (Figure 1).

Vila Itororó was Francisco de Castro's endeavor between 1910 and 1920. He passed away in 1932, leaving behind a massive debt and Vila Itororós mortgage. The mortgage lenders owned the buildings during the 1930s, and only in the 1940s would the property be transferred to the Santa Casa de Indaiatuba, a charity hospital. This institution will detain the rights over the land up until the city government reclaimed the area in 2006. The site received several waves of tenants over the course of years, all of these paying rent to Castro or Camargo as the events described took place.

The exceptionality of Vila Itororó, however, is not limited to its architecture, it is also due to the nature in which 


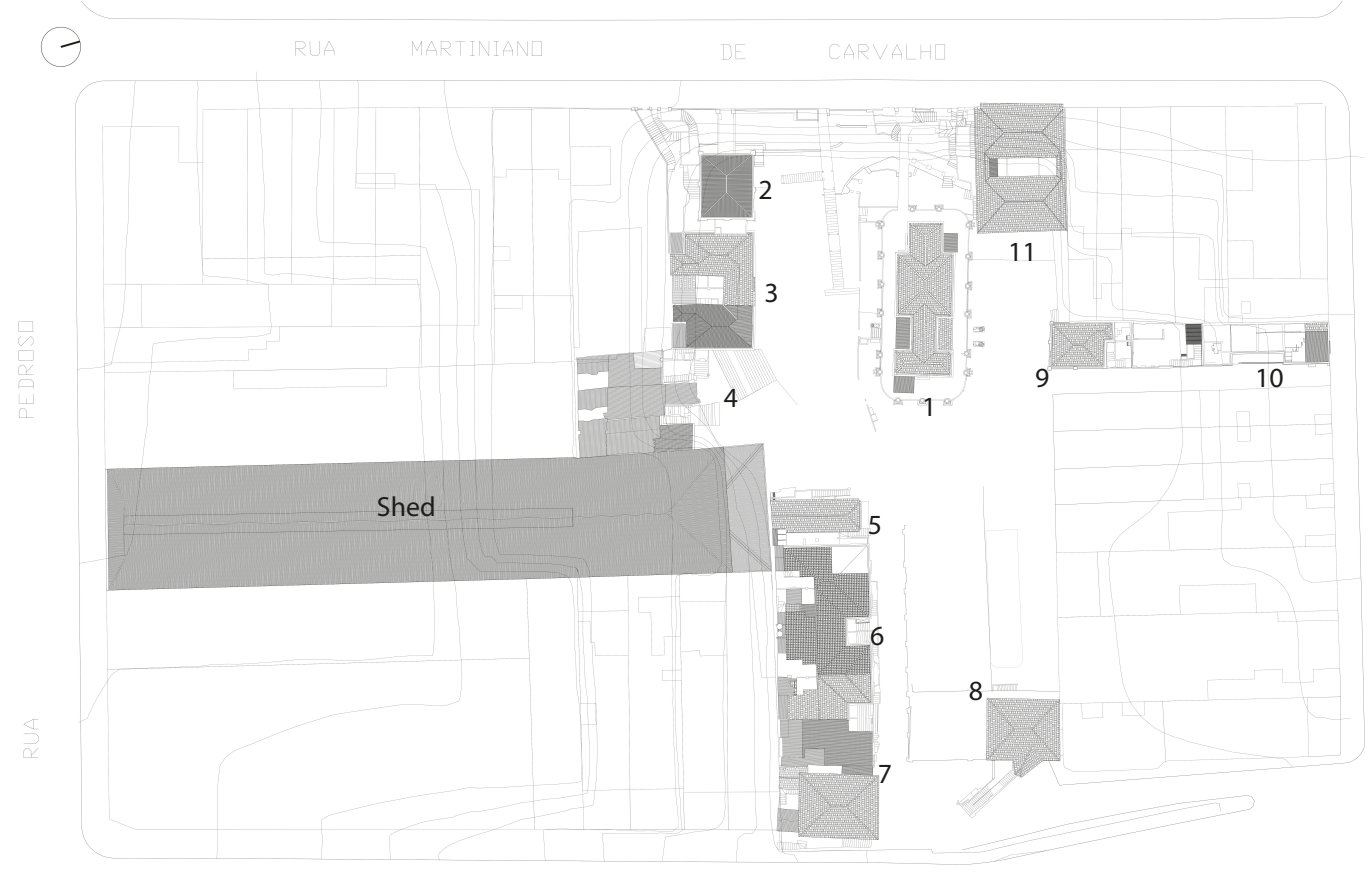

Figure 1 Site plan of Vila Itororó, with the buildings numbered according to the project sectorisation (Source: the 1 author).
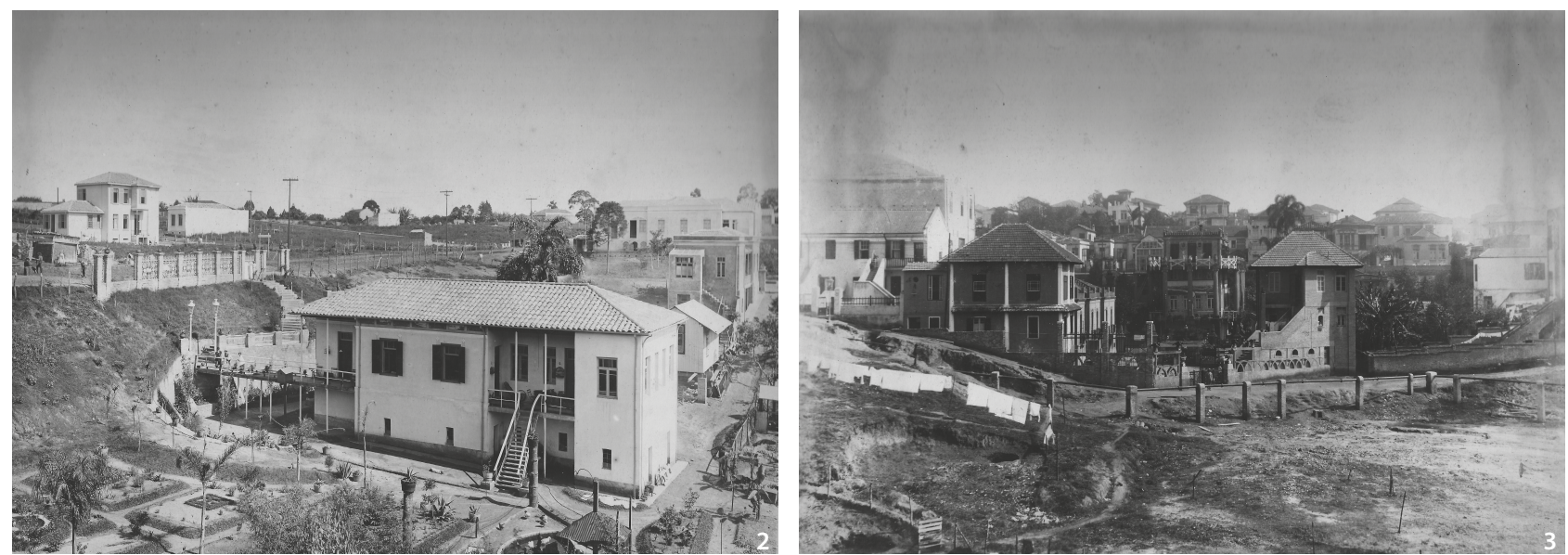

Figure 2 Vila Itororó situated below Martiniano de Carvalho Street. The house in the foreground would be altered by Francisco de Castro to later become the 'Mansion', between 1918 and 1922 (Source: Acervus of Milu Leite, c. 1914).

Figure 3 Vila Itororó as seen from the valley. The 'lower Vila' would open itself to the valley (Source: Acervus of Milu Leite, date unknown).

the tenants settled. The design of the houses suggests that these were intended for middle-class families, which differs from most other villas where the housing was usually intended for the industrial working class. Over the course of years the overall occupation impoverished and became denser. The houses decayed as the number of tenants increased.

It is believed that Vila Itororó was divided, yet not segregated, by class. The higher classes were composed of wealthier tenants, the landlord himself and eventual services personnel, while the lower classes were mainly poorer tenants. The reason for this belief are findings of enclosures and fences throughout the site, mainly around the houses on Martiniano de Carvalho Street the 'upper street'. Possibly, Vila Itororó was perceived as two different vilas, one that faced the streets of Bela Vista's neighbourhood and the other that faced the lowlands near the river (Figure 2, Figure 3). After Castro's death this division fell apart and eventually led to the further subdivision of what was formerly his private mansion. Around the same time, a pool club was established on the lowlands (Figure 4). This period marks the moment in which the public/collective realm of the block are explored, and the connection from the upper street and the lowlands are defined.

The first rehabilitation projects took place in the 1970s, without previous research or thorough surveys. When 


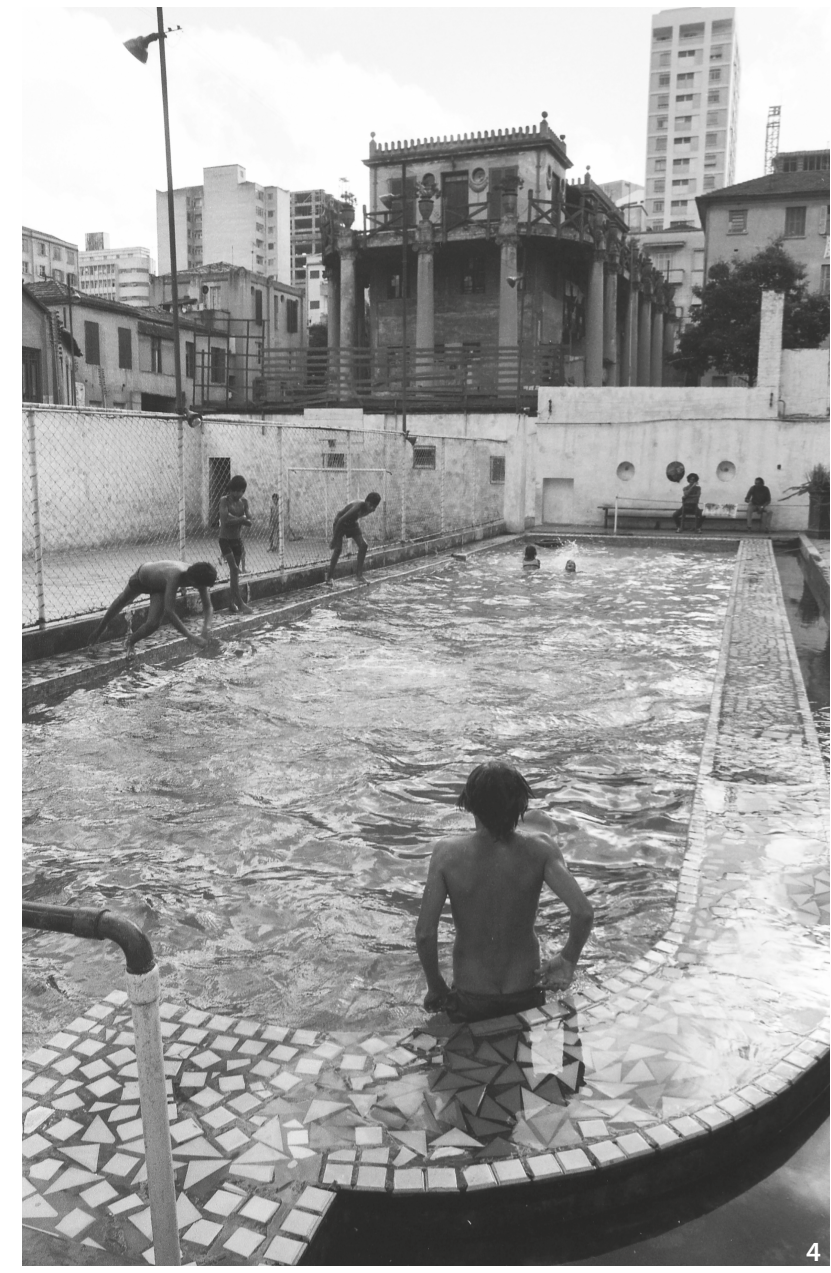

Figure 4 The club pool c. 1970 (Source: Benedito Toledo, date unknown).

we first began developing our projects, we performed adequate surveys and research of the constructions, and by doing so we found a series of cultural values derived from information such as layouts, which we found represented a state of the art practice for the period in which they were conceived (from the $19^{\text {th }}$ to the $20^{\text {th }}$ century).

The buildings' internal layouts are quite similar: they present a guest room or master bedroom in the front, other bedrooms in the centre, a kitchen, and bathrooms in the back. The main typologies were systematised by our studies in descriptive schemes (Figure 5a-5d).

This catalog reveals some peculiarities: if, on the one hand, some typologies are disseminated patterns at the time (Figure $5 a-5 b$ ), others are less common in 'ordinary' civil construction (Figure $5 c-5 d$ ); curiously some of them (Figure 5d) also appear in the first modernist houses built by Gregori Warchavchik in the 1920s-a Russianborn architect trained in Rome, precursor of the Modern Movement in São Paulo. This fact demonstrates that the relationship between both of these agents should be better
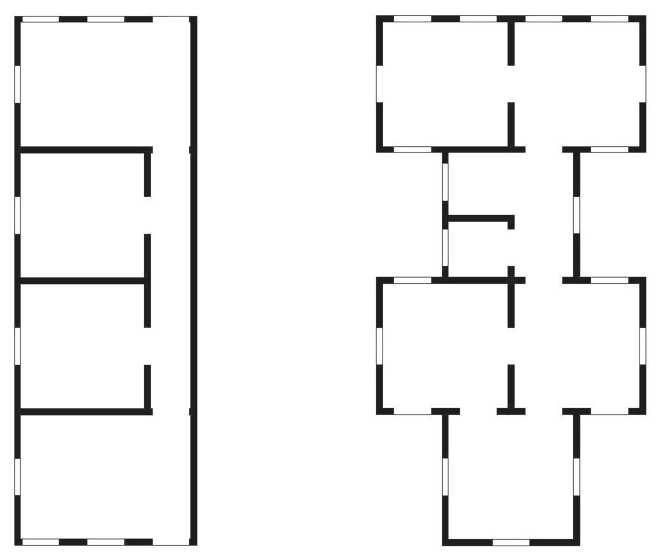

$5 a$

$5 b$
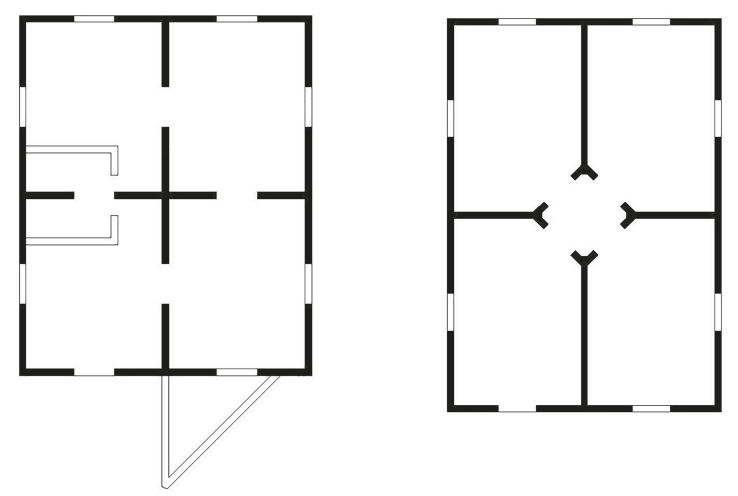

$5 d$

Figure 5 (a) Type 1; (b) Type 2; (c) Type 3; (d) Type 4 (Source: Instituto Pedra, 2017).

investigated, seen as the official historiography points the architects of the Brazilian modern movement in an attitude of vehement denial to everything that referred to the existing civil construction, of nineteenth century tradition.

\section{Recent Engagements: The Cultural Centre}

After an extensive process that began around the 1970s, Vila Itororó gained the official status of a heritage site by São Paulo's city (2002) and state (2005) governments, resulting in various levels of protection for the constructions on site. What followed was a decree of 'public interest' which would lead to the removal of the tenants of Vila Itororó, a process that started in 2011 and ended by 2013. As a result, the state authority of São Paulo transferred the usage rights of the land to the city government under the conditions that the buildings would be conserved and that a cultural centre was to be installed on the site. Initially, the city government hired architect Décio Tozzi and his team to draft a proposal for the site, taking advantage of 


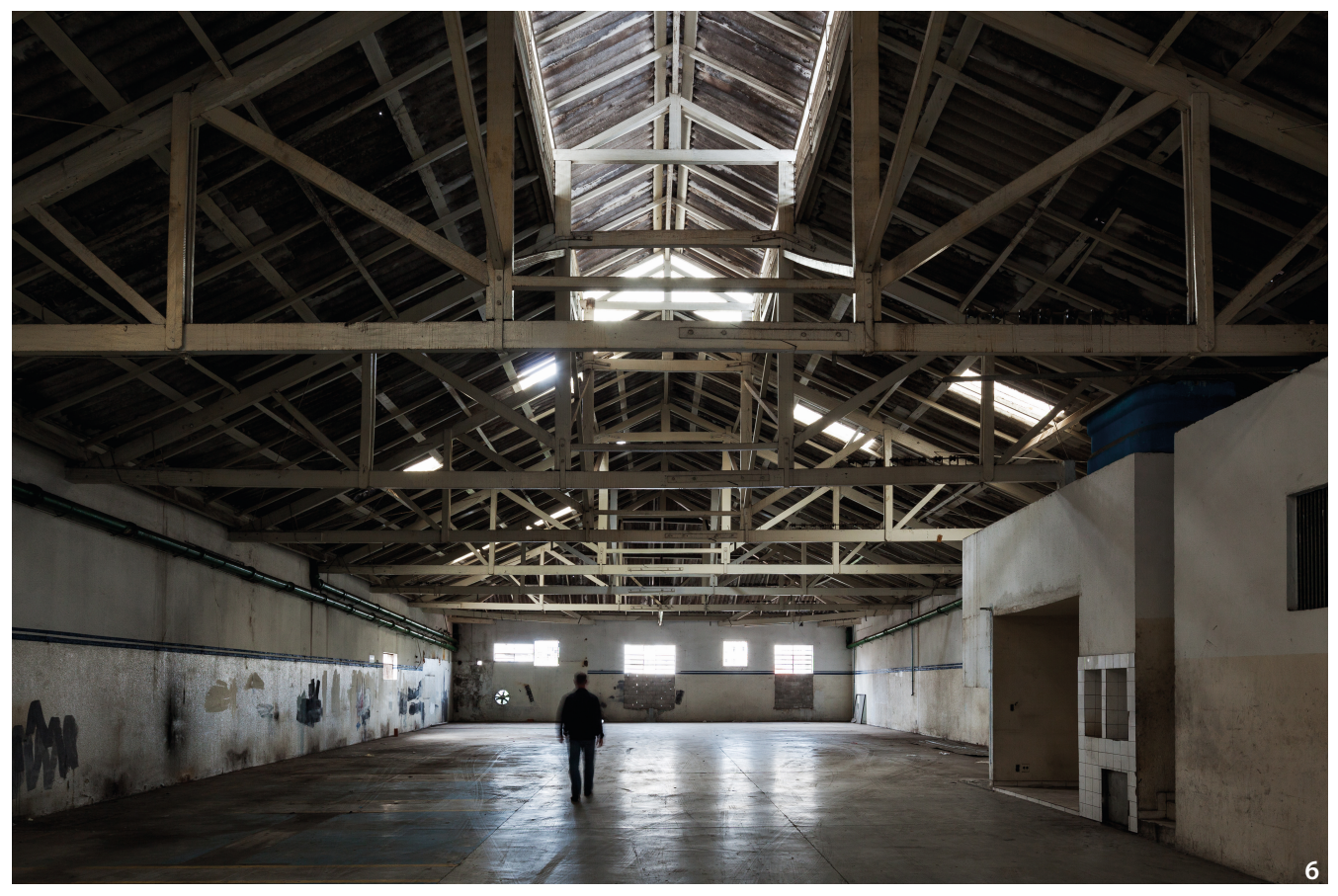

Figure 6 Shed previous to the restoration work (Source: Nelson Kon, 2014).

studies the team had been carrying out since 1974. The proposal was designed, but not hired to build.

With the change in office at the city hall in 2013, the new administration began to notice the challenges that hiring Tozzi's proposal would present financially, and decided to pursue state cultural incentives to enable the project. It was in this context that Instituto Pedra proposed a cultural and financing project through the Federal Mecenate Law (Rouanet Law) in 2014. The project covered management of the conservation, restoration and reuse projects. It is on these activities that this essay will focus.

\section{Open Site Cultural Centre}

Elaborated in the 1970 s, the first cultural project considered for Vila Itororó was a traditional approach to cultural centres. This approach included restoring the façades and redesigning the buildings' structures to enable internal use. The occupation of these buildings would happen with the programs defined by the city government which included: diverse cultural uses, a children's library, restaurants, a Vila Itororó and adjacent neighbourhoods themed museum, a redesigned landscape, and several multi-use facilities.

In 2014, with the initial feasibility of financing in sight, the administration, now with a more seasoned approach and perception of the site, its future management, and the project that had been developed up until then, decided to divide the project in phases in order to collect funds phase by phase throughout the process. Considering that running a 'traditional' cultural centre would be a higher cost operation and wasn't an adequate program for the regions' context, the administration decided to investigate possible alternatives for a management model for Vila Itororó and to reassess the original proposal, identifying opportunities for innovation and programs that contributed to a financially sustainable operation.

What followed was an intense process of research and reflection that could enlighten the current team on subjects such as the new uses this place could offer. The local community is a key player in this process, fostering an environment that is prone to develop new ideas and solutions. Using resources such as the industrial shed, it is possible to concentrate these activities and use the construction site as a trial lab for future uses and possible uses, engaging the public to participate in the discussion, creating the, necessarily ephemeral, Open Site Cultural Centre (Figure 6). The uses on site would start happening where there were conditions while the restoration projects took place on other buildings on site. This allowed for a dynamic proposal of uses that met halfway between topdown and bottom-up approaches.

The main activities are divided into three groups: site guided tours, spontaneous uses (in which the public is encouraged to use the space in whichever way they see fit), and training workshops many of which happen by taking advantage of auxiliary facilities on site, such as the timber workshop (Figure 7, Figure 8). Over time, other cultural activities started to emerge such as a yoga group, a circus 

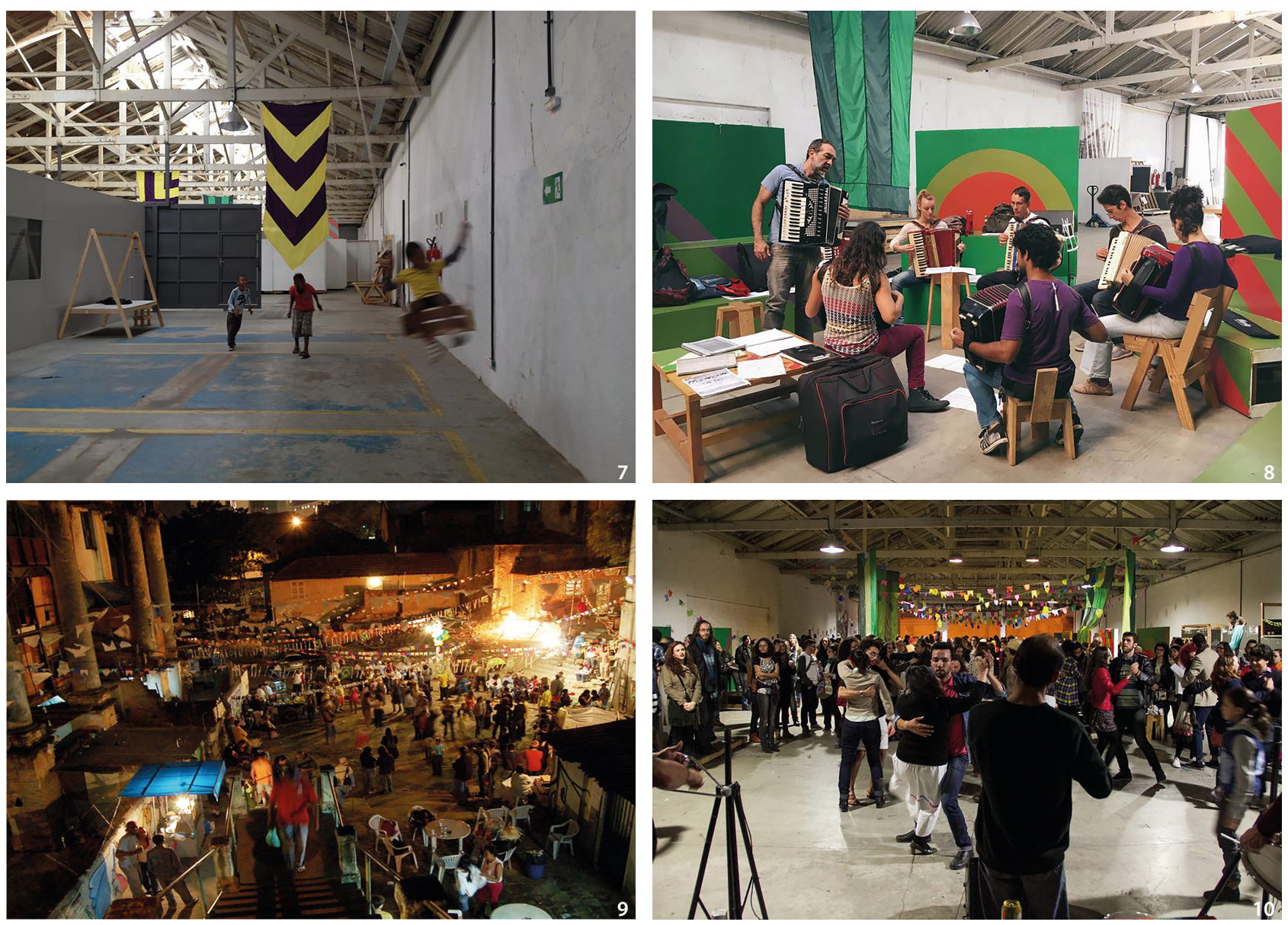

Figure 7 Spontaneous uses of the shed, playground (Source: Instituto Pedra, 2015).

Figure 8 Spontaneous uses of the shed, accordion classe (Source: Instituto Pedra, 2015).

Figure 9 June Seasonal Party at Vila Itororó. A traditional event used to occur at Vila, before the removal of the tenants (Source:

Lígia Pinheiro/Mosaico, 2006).

Figure 10 June Seasonal Party at Vila Itororó. Party held during the restoration (Source: Instituto Pedra, 2016).

group, a ballroom dancing group, a theatre group. Eventually, other institutions became partners and a part of Vila Itororós activities, such as Goethe Institute and a public FabLab. Occasionally, Vila Itororó also promotes academic events, such as seminars, discussions and workshops, which help to disseminate work and activities happening on site.

The involvement of former tenants (who stood against their own removal in a pro-housing movement) and current local residents is considered essential to the legitimacy of the actions and proposals for the area. In the activities hosted at Vila Itororó, these former tenants and local residents are granted priority admittance in order to help ensure that the local community engages with the cultural centre. The role that the former tenants have in the proposal of new uses is paramount. It is alongside their views, perceptions, stories and memories that several of the restoration and reuse decisions are made. Namely, testimonials of how life happened at Vila Itororó, extracted from the research of Sarah Feldman and Ana
Castro (2018), have been used as a practice reference fomented by the cultural program. Activities present in the testimonials such as 'Festa Junina', a seasonal party, played a strong role in aggregating the community in the beginning of the occupation at the Vila. This festivity (festa junina) now happens within the premises of the industrial shed-a key element of the experimental cultural centre-until other areas become suitable for occupation (Figure 9, Figure 10).

\section{New Directions for Restoration}

Parallel to this, the restoration interventions were also subject to alterations due to the new demands that presented themselves and also due to the challenges of carrying out the former design, which was based on an inaccurate and outdated site survey. It is believed that these challenges arose amid the context of the removal of the former tenants, a tumultuous process in which the designers did not have access to the buildings, being 

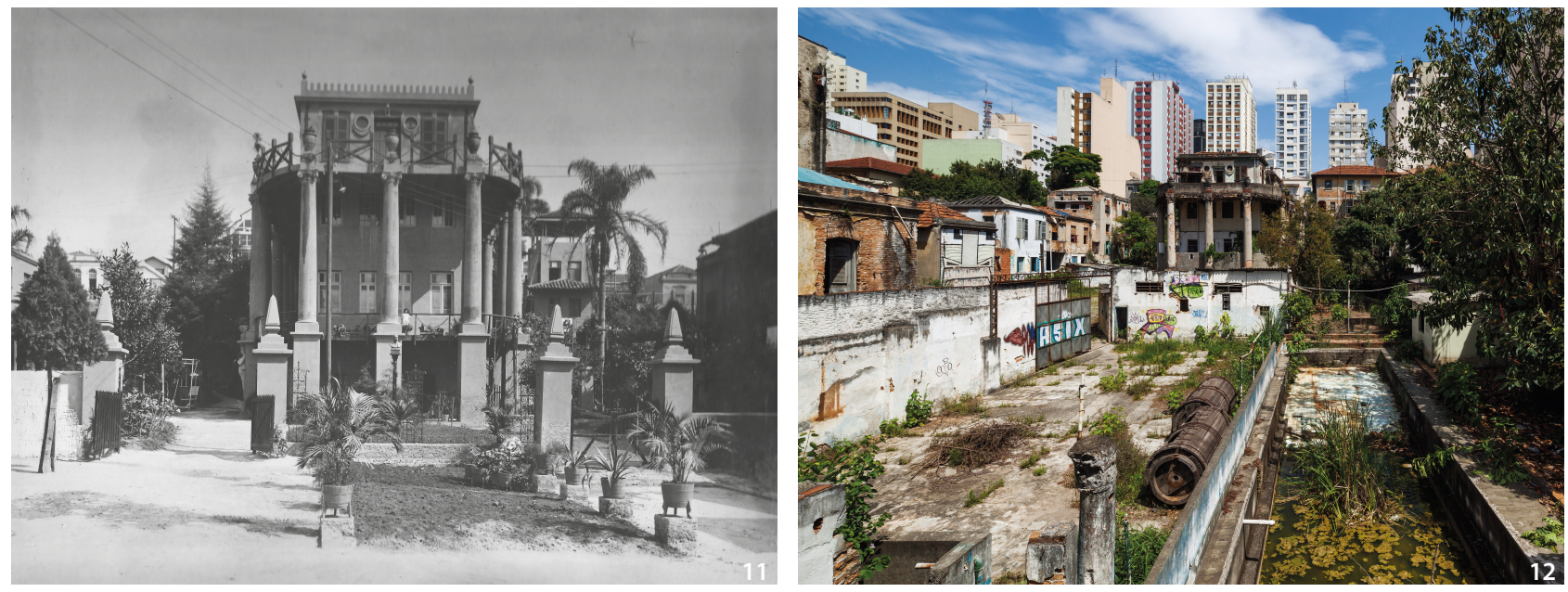

Figure 11 Vila Itororó circa 1930 (Source: Acervus Milu Leite, date unknown). Figure 12 Vila Itororó before restoration (Source: Nelson Kon, 2014).

forced to rely on assumptions based solely on the available historical documentation. This, however, showed later to be an insufficient approach.

Generally, the buildings on site are in an advanced state of decay and were substantially modified over the course of years rendering the historical documentation outdated (Figure 11, Figure 12). The next step had to be the creation of an accurate database and inventory that would only be possible through diligent prospection of each building on site, a process that would lead to a series of findings. These findings validated the practice of applied research at Vila Itororó, because of their value in the design process and also in understanding the complex nature of this site. Examples of the impact of some findings include, but are not limited to, the comprehension that typologies and construction techniques showcased historic-artistic values that need to be preserved.

\section{Construction and Cultural Programming}

This twofold relationship that the cultural project has developed has deepened the comprehension of Vila Itororó not only as a built environment but also as a cultural equipment for a whole community. The research carried out for the restoration projects is frequently a source of activities for the public, and the activities and interactions with the public are also frequent sources of new information that help guide the design team.

As examples of this dynamics we can highlight, on the one hand, events motivated from the restoration works:

- Open seminars: lectures, debates and visits to the construction site for the Heritage Day $(2016,2017)$, an event organised by the Municipal Department of Culture. It covers several monuments belonging to the municipality and has a large presence of varied public.

- Specific seminars: building on the difficulties of diagnosis raised by the 'Palacete', the main building of the complex, a partnership was held to discuss strategies for surveying the building, with two scientific research groups: GCOR-Arquitetura (Unicamp, Brazil) and DIAPReM (Ferrara, Italy). This partnership led to a seminar (2015) directed to a specialised audience, to discuss the subject of architectural survey (a practice not very regulated in Brazil), based on three main methods: direct survey (Instituto Pedra), photogrammetry (GCOR-Arquitetura) and 3D laserscanning (DIAPReM). In addition to the seminar, 3D laser-scanner demonstration activities were conducted, which also generated new databases for building survey. Thus, at the same time that specific training was promoted, knowledge was generated directly related to the restoration.

- Craft workshops: a demonstration workshop (2016) on the reproduction of ornaments in plaster and ferro-cement, opened to a subscribed but not specific public, was carried out through a partnership with the construction company that works on the project (Concrejato). In addition to it, workshops related to other materials such as timber, for example, are planned to occur.

On the other hand, we showcase some demands that come through the programming and the public, which also impacted the construction site:

- Artistic installations: from a curatorial work, two artistic installations were promoted: Patterns of the Villa (Monica Nador 2015), in which visual elements were collected from Vila Itororó, and collectively 

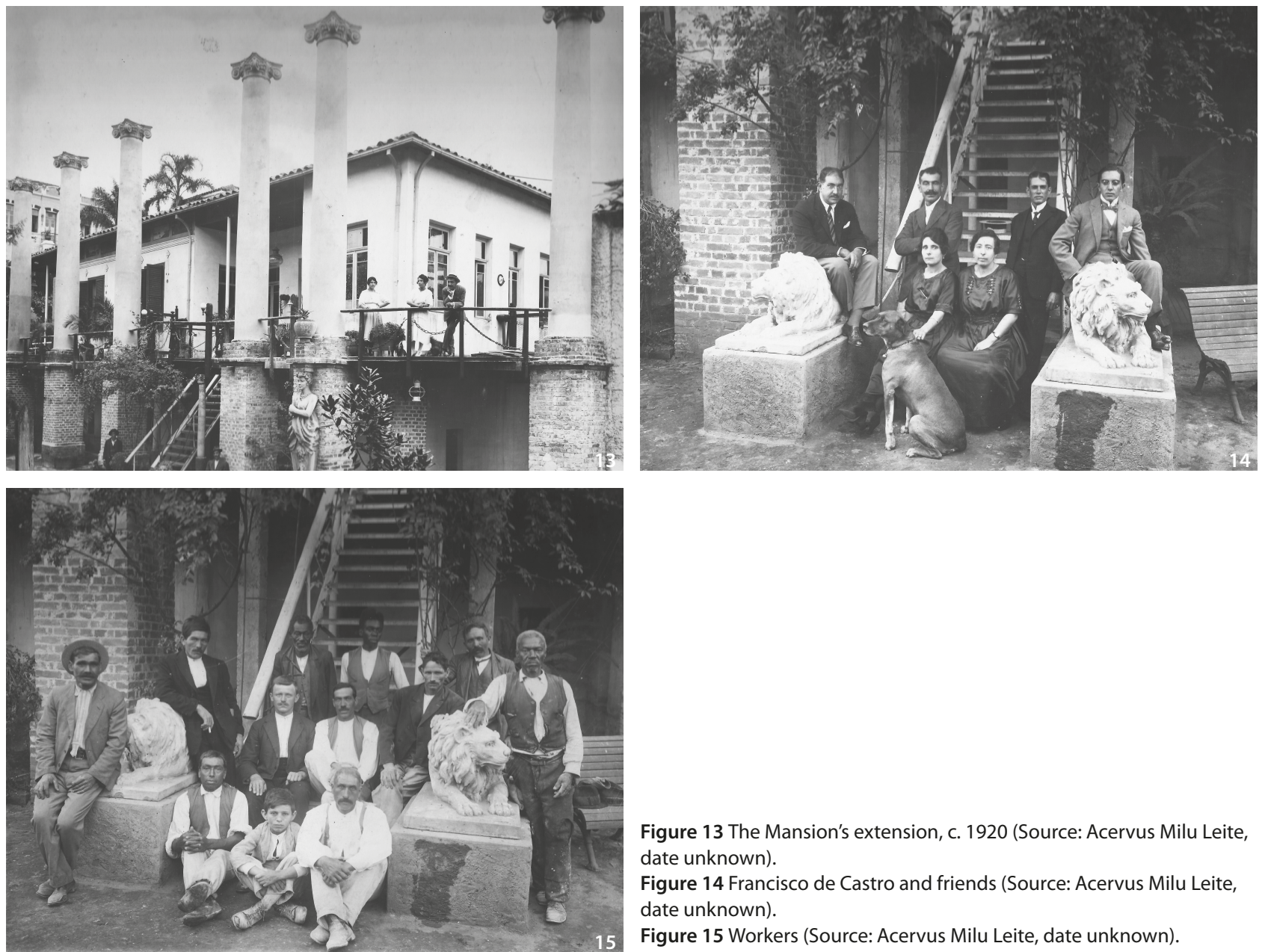

Figure 13 The Mansion's extension, c. 1920 (Source: Acervus Milu Leite, date unknown).

Figure 14 Francisco de Castro and friends (Source: Acervus Milu Leite, date unknown).

Figure 15 Workers (Source: Acervus Milu Leite, date unknown).

transformed into stencils that were used in the ornamentation of the shed. Panapanã (Carla Zacagnini 2016), in which a 'butterfly garden' was produced with movable flower boxes, with the purpose of attracting the public to the visits to the work and enjoyment of the common spaces.

- Partnerships in artistic events: on a few occasions Vila Itororó hosted theatre plays at important national events/companies: Teatro da Vertigem (The Child, 2015), which required changes in the space of the joinery to accommodate the scenarios. Teatro de Narradores (Voodoo City, 2016), held in the courtyards of the construction site, on behalf of the MITsp (Mostra Internacional de Teatro de São Paulo, International Theatre Show of São Paulo). Both were box office success, promoting greater approximation of the public with Vila Itororó, especially since the themes approached correlate with the local history. In addition, we highlight the presence of other events, such as the XI Biennale of Architecture of São Paulo (2017), which had works hosted in the Village, between the construction site and the shed, also with themes related to the place.

- Partnerships in the construction site: the interest for the construction site and its monuments motivated a partnership with the Goethe Institute-São Paulo for the ostensive use of one of the houses of the complex (2016). In order to achieve this, the building was repaired on time and consolidated, which is now being used for an artistic residency program (Goethe na Vila), which promotes experiences between artists and the public, in parallel with the construction site.

- Collective constructions: the spaces of most intensive collective use were made possible through collective construction workshops: The Shed's furniture, which until now serves as a support to the public, was conceived and built collectively during a workshop (2015) promoted in partnership with the group Constructlab (France/Germany), inaugurating the Cultural Centre in the shed. On the other hand, the space where the Goethe residences in the Village take place was conceived and built through a workshop (2016) in partnership with the Raumlabor group (Germany). 


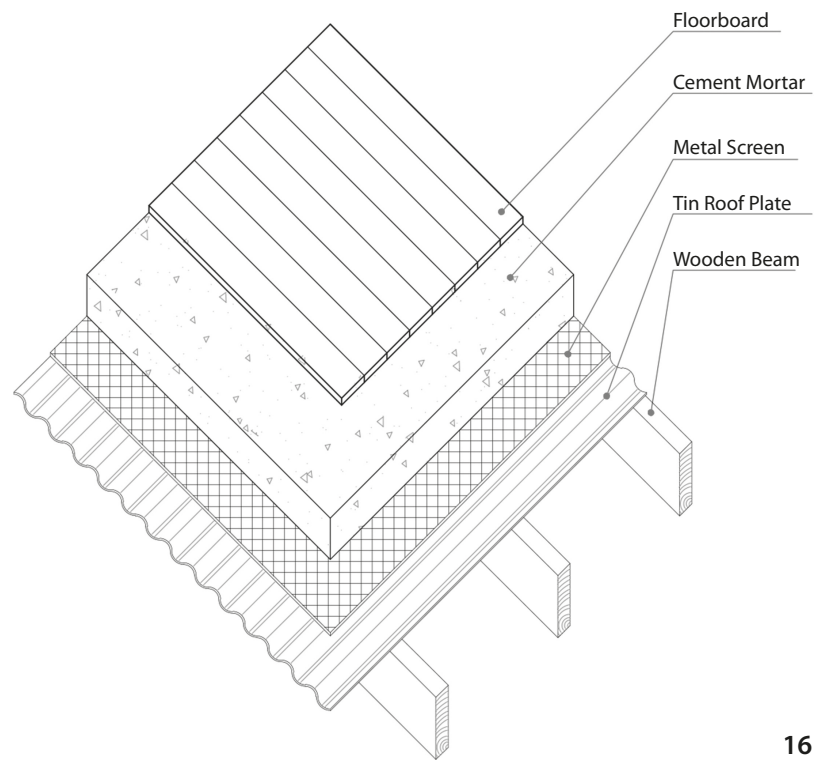

Figure 16 Deployé constructive system illustrated (Source: Instituto Pedra, 2015). not to scale.

- Festivals and picnics: as a consequence of the events of greater collective involvement, interaction activities such as parties and meals produced by all are carried out, a very aggregative factor between workers and the public involved.

It should be noted that the structures that have been completed serve the public visiting the site, as well as the teams that work there, from the architects to the workers themselves.

In addition, because of the publicity of the project in the media, people have, voluntarily, contacted the team after taking knowledge of the project to offer photos from private collections that feature Vila Itororó. These photos had a fundamental role in identifying relevant iconography (Figure 13-15).

\section{Recent Findings}

The construction techniques displayed on site are of wide variety and alongside the typologies and morphology of the complex become central elements that justify the preservation efforts placed at Vila Itororó. All the buildings built by Castro are made of load bearing brickwork, with occasional reinforcements made in diverse materials such as low-resistance mortar, reinforced concrete or metal and timber frameworks. This diversity also highlights the creativity in the solutions, often being made of reused materials of different shapes and sizes. Regarding the horizontal structures, the variety is composed of wooden floors in internal areas and vaulted slabs in external areas; there are also undated improvised reinforced cement slabs, that use various smithed elements as a reinforcement as well as deployé systems (experimental 'proto-modern' slabs structured by various layers of cementicious materials spread over metal frames. These elements are also present in the houses of Warchavchik) (Figure 16). These findings significantly alter the perception of the object of study as well as the guidelines for the restoration project.

Interestingly, such discoveries were only possible through a straightforward study of the object, done in a rigorous way. The new findings ultimately influenced the conservation guidelines supported by the project, as new cultural values were brought to light.

If previously the criteria for preservation were based solely on the exceptionality of few buildings, today Vila Iororó is understood as one of the few remnants of civil architecture in São Paulo during the transition of the $19^{\text {th }}$ century to the modern metropolis of the $20^{\text {th }}$ century. The typologies of the buildings keeps alive this memory, along with the great quantity of parietal paintings found in almost all the buildings. In addition to demonstrating ordinary civil construction, the set presents experiments of new constructive systems that would only later be consolidated, which would also be shared with the modern movement, as has already been said.

\section{Innovative Character}

The ongoing operations in Vila Itororó represent today the rupture of a series of paradigms in relation to projects of this nature, in Brazil, as we can highlight:

In terms of scientific rigor: for successful approach to a complex monument, the emphasis given to research is critical to the success of the project. As we have seen, this investment allowed for a series of discoveries that eventually influenced the criteria for restoration. In addition, given the breadth of use possibilities, it is possible that the findings of the architecture may also influence the final uses and program. For the time being, we emphasise that research in architecture already influences the programming of the Cultural Centre-and the latter, as a return, brings demands that influence, in turn, several operations at the construction site.

In terms of public resource management: by making parts available to the public prior to the completion of the work, it is possible to deliver record-time gains to the community involved. This becomes advantageous at a time of economic crisis, such as what the country is experiencing today, where an inflow of financial resources has not been guaranteed especially for the field of culture, 
and for large works such as this. In addition, the use ostensive is able to guarantee maintenance of the buildings that are gradually being made available, besides generating social pressure for the continuation of the project.

Involvement of society: approaching the community the way it has been approached, enables an 'open' working process, capable of listening in a very sensitive way to the demands of those who will actually use the services offered, testing which ones are more relevant than others, for a program of future uses; in addition, it is capable of promoting capacity building and a sense of involvement with heritage by bringing the community closer, not only to the monument, but to the crafts involved with the construction site. This reinforces the public character of heritage, allowing truly democratic appropriations of assets of collective interest.

The team is aware of specific actions to promote community ownership of the cultural heritage, but not in an ostensive manner, as in Vila Itororó. If, on the one hand, we started with Open Works, or Construction Site's School in Europe, which promote guided visits, or even allow the use of their structures by the public (such as woodworking, for example), it is difficult to think of cases where these actions became decisive for the definition of the program of uses and strategy of restoration.

This condition is now, we believe, due to a sum of peculiarities that surround Vila Itororó: the peculiarity of its architecture and history; the controversy involving the installation of a cultural centre in a historical place of residence, before, in a centralised and hierarchical way; the gaps in historical and direct research related to the object of studies; the residential character of its architecture; the scale of the monument, which is part of an urban complex.

Another factor capable of allowing this peculiarity is, in fact, an inherent contradiction to the functioning of the Brazilian State. If on the one hand the national republican tradition presents a historical authoritarian and centralising character, the functioning of the state bureaucracy is not capable of offering integrated control of public actions.

In this way, the State does not exercise a strict quality control of the services it has contracted, in an outsourced manner, due to the lack of technical criteria that regulate the work in sensitive fields, as in the case of culture and, specifically, involving actions of restoration. This condition opens the door to the contracting of projects with little methodological rigor in research, as is the case for projects conceived since 1974.

In addition, government actions are rarely structured in an integrated way, remaining subordinated to the policies of specific secretariats. In this way, a complex action like the restoration of a monument with individual and urban, cultural and social characteristics, simultaneously, is at the margin of an integrated understanding. Vila Itororó, today, is subordinated only to the Municipal Department of Culture, which still has little relationship with secretariats related to urban development, and is not an object of more comprehensive actions, such as the new Strategic Master Plan of São Paulo (Plano Diretor Estratégico).

In this sense, we can observe that policies related to cultural heritage rarely end up finding support in the actions of urban planning. This is due, in part, to the bureaucratic manners in which the state secretariats function, as we have mentioned, but also due to a crisis between competencies in the field of architecture and urbanism, where from the moment of greatest growth in the country (for example, under authoritarian regimes, in 1970s), teaching as a whole has turned to increasingly specific and less comprehensive formations.

On the other hand, the apparently centralist character of the state, of which we speak, was gradually disrupted by the re-democratisation of Brazil in the late 1980s, which allows today the simultaneous coexistence of society with two paradigms of state, in the same bureaucratic apparatus: one, more central and authoritarian, and another, with actions that allow specific democratic openings.

If this generates, on one hand, a certain struggle in coordinating integrated government actions, on the other, it opens the door to experimental actions that seek to promote integrated approaches to complex problems, as is the case with this project.

Today, the ongoing actions in Vila Itororó begin to promote dialogues among Municipal Departments. One of the possible paths pointed out with this, is a future management model structured as a kind of 'condominium' between institutions that participate in Vila Itororó, including public and private agents, since always with public interest.

\section{General Conclusions}

Vila Itororó went through a 40 year long process to be recognised and officially identified as a heritage site and complex. The process itself was complex and controversial, and involved matters relative to public housing in the city centre, which have related to the understanding of the fundamental meaning of heritage.

While these processes unravelled the comprehension 


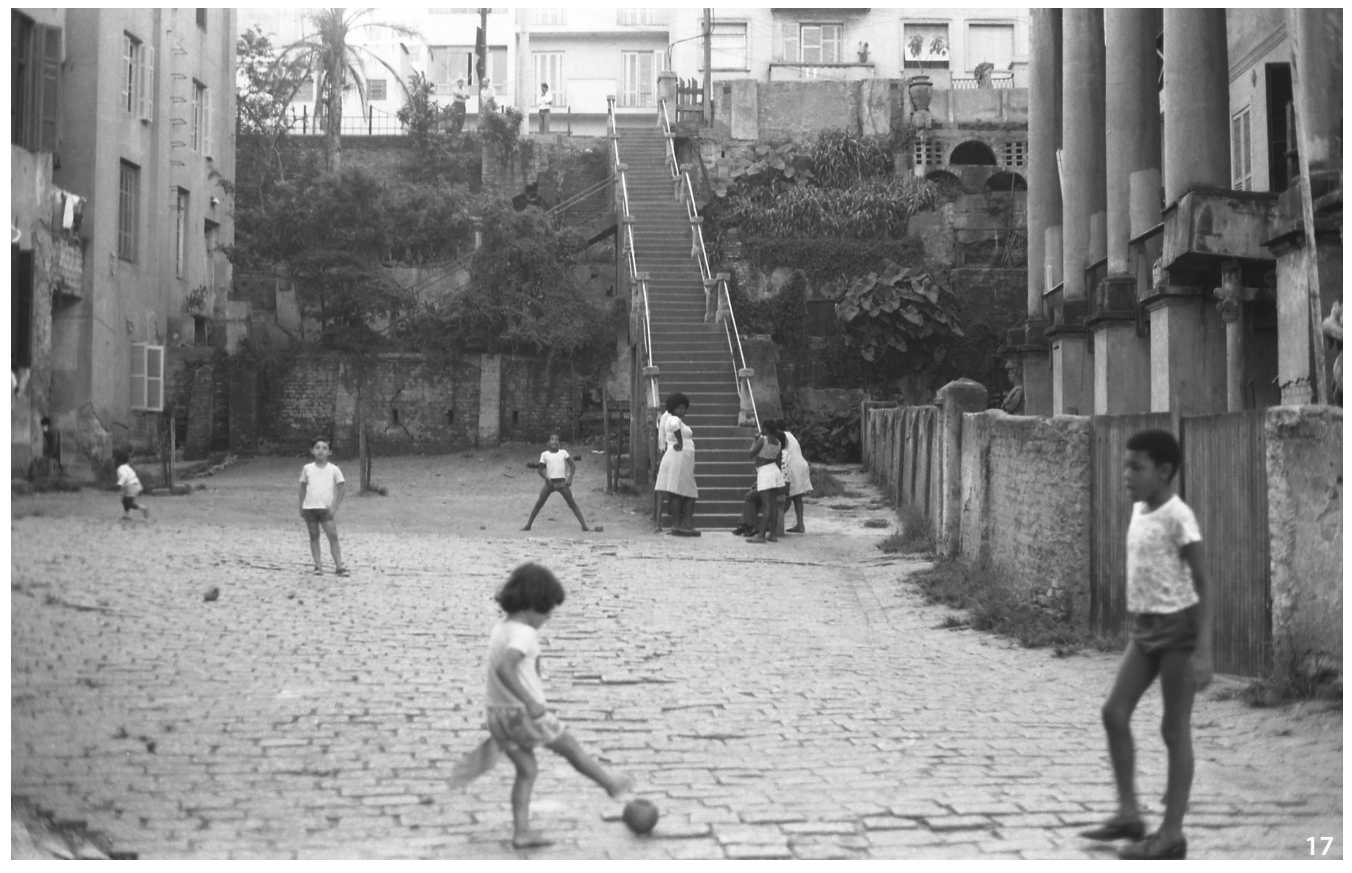

Figure 17 Vila Itororó tenants circa 1970 (Source: Benedito Toledo, date unknown). of the relationship between housing, heritage, and the paradigms they infer allowed for a new grasp on the conflicts and restrictions these matters present, and it became clear that having a profound appreciation of heritage and what it means better resolves the existing conflicts with housing. In accordance to this, new studies (still in course) point to the preservation of remnant materiality as a valid approach for this project, wherein the plurality of values found in the complex's many phases would require a different criteria for analysing what and how to preserve. Traditional monumentality, with artistic prime and a regulated design, are either absent or were subverted and altered to the point in which they become just as relevant as the older remnant materialities.

Behind such a complexity lies its relevance and the main reason that makes it worth preserving: Vila Itororó showcases a series of different time periods and the construction techniques associated to them. Its construction marks a transition period between an imperial province and an industrial metropolis. The solutions that range within these periods are, in many cases, still present within the site as original, adapted, experimental or hybrid solutions. These were motivated by a shortage in materials and resources associated once with the creativity of the modern builder's ethos, and again with the wit of the poorer tenants that readapted the places for their own needs (Figure 17).

In this sense, one could claim that Vila Itororó has an essential 'anti-monument' quality, where the monumental value may lie in the 'inglorious' solutions or even within the 'decadence of former prime' synthesis of an inconclusive metropolitan attempt-perhaps a significant contribution that São Paulo can make for heritage research and practice in Brazil.

These claims are not recent ones, in fact they have made since the 1980s by preservation intellectual representatives of the regional cultural heritage organs. Curiously noting the so-called contradiction between the monumental and residential (housing) purposes of the complex.

The team believes that only through an integrated and de facto multidisciplinary approach, will there exist a chance to address these conflicting views and also provide a truly comprehensive preservation of the complex-in which the local community, through a sense of belonging and the resignification, will help keep.

In regard to the cultural project-the experimental cultural centre and the restoration projects-it has been exciting to follow how well they structured a feedback loop, fomenting mutual subsidies for the projects' development. These, in turn, favour the overall area of restoration seen as how it may bring society closer to this field. This, perhaps might be a challenge worth concern: without an operational framework that can intervene on heritage, not only will the restorations cease to happen, but also will the academic production on the subject which originates essentially from restoration practice.

As a synthesis of these dynamics, the case in point allowed for interesting experiences within architectural survey and site prospections, which in turn helped form a new technical and cultural perspective of Vila Itororó, 
bringing to light matters long forgotten such as the stories of the people who lived there, how they lived there, how the complex came about, the challenges of construction, amongst others.

The contribution of Vila Itororó and of its materialities' cultural wealth may just be as a case study of the potential cognitive process that can emerge from the prospection campaigns and architectural surveys, that are still incipient as a practice in Brazil.

\section{References}

Ab’saber, Aziz. N. 1957. "Geomorfologia do sítio urbano de São Paulo”. PhD diss., University of São Paulo.

Castro, Ana, and Feldman Sarah. 2018. Vila Itororó: Uma história em três atos. São Paulo: Instituto Pedra.

Docci, Mario, and Maestri Diego. 2010. Manuale di rilevamento architettonico e urbano. Bari: Gius. Laterza \& Figli.

Freitas, Pedro Murilo G. de. 2010. "O Desenho e o Reconhecimento do Objeto Histórico: Os princípios metodológicos do projeto de restauro arquitetônico". Master Thesis, University of Campinas.

Mappa Topographico do Município de São Paulo. Map. São Paulo: Sara Brasil s/a, 1930.

Toledo, Benedito L. de. Vila Itororó. São Paulo: Instituto Pedra, 2015. 